\title{
Pendampingan Peningkatan Penyelesaian Soal Berbasis Masalah pada Siswa SMKN 2 Bima
}

\author{
Azra Fauzi \& Ewisahrani \\ Dosen STKIP Harapan Bima
}

\begin{abstract}
Abstrak; Kegiatan Pengabdian ini bertujuan untuk menjelaskan proses pendampingan penyelesaian soal berbasis masalah pada siswa SMKN 2 Bima. Metode pelaksanaan kegiatan ini terdiri dari: a) persiapan, b) pendampingan, c) Implementasi, dan evaluasi serta refleksi. Subjek penelitian ini adalah 12 siswa SMKN 2 Bima yang lulus tes awal penjaringan awal olimpiade tingkat sekolah. Hasil kegiatan pengabdian ini berupa hasil kerja siswa selama proses pendampingan, lembar observasi selama proses kegiatan pendampingan dan evaluasi hasil pendampingan. Hasil dari pengabdian ini adalah kegiatan pendampingan yang di dalamnya terdapat langkah-langkah: a) Analisis pendahuluan, b) penyusunan soal pemecahan masalah, c) Kegiatan pendampingan, d) kegiatan akhir yang berupa refleksi kegiatan.
\end{abstract}

Kata Kunci: Pendampingan dan Soal Berbasis Masalah

Abstract; This devotional activity aims to explain the process of facilitation of problembased problem solving on students of SMKN 2 Bima. Method of implementation of this activity consists of: a) preparation, b) mentoring, c) Implementation, and evaluation and reflection. The subjects of this study were 12 students of SMKN 2 Bima who passed the initial preliminary examination of early olympic level of school.The results of this devotional activity in the form of student work during the mentoring process, the observation sheet during the process of mentoring activities and evaluation of the outcome of mentoring. The result of this dedication is a mentoring activity in which there are steps: a) Preliminary analysis, b) preparation of problem solving problems, c) Assistance activities, d) final activities in the form of reflection of activities.

Keywords: Problem-Based Assistance and Problems

\section{Pendahuluan}

Olimpiade merupakan salah satu kegiatan yang dilakukan oleh siswa setara MI/SD, SMP/MTS, SMA/MA dan PT. Seringkali kegiatan ini jarang diminati siswa maupun mahasiswa karena soal yang ada pada olimpiade tersebut dalam kategori soal berbasis masalah. Soal berbasis masalah merupakan salah satu jenis soal yang memiliki kriteria sebagai berikut: a) soalnya merupakan soal tidak rutin, b) dalam menyelesaikan soal tersebut memerlukan strategi, dan c) soalnya berdasarkan permasalahan yang adaRatnaningsih, N. (2003).

Ada beragam kondisi yang membuat pengajaran tak optimal terserap oleh siswa. Misalnya, anak kurang konsentrasi saat guru menjelaskan. Terkadang, anak-anak terlihat memperhatikan pelajaran tetapi sebenarnya mereka sedang melamun atau bahkan mengerjakan hal lain. Pelajar juga seringkali kurang minat dengan pelajarannya. Atau, bisa jadi siswa tak suka dengan metode ajar gurunya. Kebanyakan guru mengajar dengan metode ceramah sehingga siswa merasa bosan. Bisa juga, fasilitas sekolah kurang menunjang. Minim perpustakaan atau alat ajar, bisa jadi di antaranya. Banyak sekali penyebab lemahnya proses pembelajaran.

Kenyataan yang ada di lapangan, jarang sekali sekolah yang mempunyai guru khusus olimpiade Fakhrudin.(2010).. Hal ini disebabkan karena guru mengalami kesulitan dalam menyelesaikan soal yang setara soal olimpiade. Selain itu biasanya guru tidak mempunyai waktu untuk melakukan pendampingan terhadap siswa yang mengikuti olimpiade. Untuk mengatasi hal tersebut biasanya sekolah mengambil pilihan merekrut 
guru olimpiade dari sekolah lain yang kompeten. Adanya kegiatan perekrutan guru tersebut menyebabkan adanya kasus bahwa guru tidak mengetahui karakter awal siswa seperti guru kelasnya. Selain pada guru, kelemahan juga berlaku pada siswa. Siswa mengalami kesulitan dalam menyelesaikan soal olimpiade. Kebanyakan siswa masih menganggap bahwa soal yang diselesaikan sama dengan soal yang ditemukan di bukubuku sekolah, sehingga strategi yang digunakan masih bersifat satu langkah.

SMKN 2 Bima merupakan salah satu sekolah yang di dalamnya terdapat lima keahlian yaitu: akuntansi, Administrasi Perkantoran, Pemasaran, Multimedia dan TKJ. Guru matematika yang ada di sekolah tersebut ada dua orang dimana setiap guru rata-rata mengajar 2-3 bidang keahlian. Hal ini menyebabkan jam mengajar setiap guru cukup padat. Sebelum tahun 2016 di sekolah tersebut belum pernah mengikuti lomba olimpiade matematika. Hal ini disebabkan karena ketidaksiapan guru dan siswa dalam mengikuti lomba olimpiade tersebut. Pada tahun 2017 dalam waktu satu tahun sekolah ini sudah mengikuti olimpiade selama dua kali. Lomba yang ada pada UMM dan pada setingkat kota malang. Hal ini merupakan salah satu keberhasilan program pengabdian dari tim pada tahun sebelumnya. Setelah tahun lalu kami memberikan pendampingan pada penyusunan perangkat pembelajaran sebagai pendukung kegiatan olimpiade. Pada tahun ini, tim kami berusaha memfokuskan pada pendampingan guru dan siswanya.

Berdasarkan permasalahan tersebut maka diperlukan pendampingan Penyelesaian Soal Berbasis Masalah pada Siswa SMKN 2 Bima.

\section{Metode Pelaksanaan}

Kegiatan pengabdian ini terdiri dari : a) persiapan, b) pelaksanaan dan c) refleksi. Berikut adalah penjelasan dari kegiatan ini.

a. Persiapan.

Kegiatan persiapan dimulai dari observasi untuk mengetahui kondisi di sekolah berkaitan dengan kegiatan olimpiade dan sistematika pendampingan yang dilakukan di sekolah serta dilakukan kegiatan wawancara dengan pihak sekolah untuk kegiatan tersebut. Berdasarkan hasil observasi dan wawancara yang telah dilakukan, tim pengabdian melakukan diskusi internal dan mengkaji literatur untuk membahas kemungkinan solusi yang dapat membantu permasalahan yang ada. Setelah diskusi tersebut dilanjutkan dengan pengkoordinasian untuk menentukan penanggung jawab pendamping olimpiade di sekolah. Dilanjutkan dengan penyusunan jadwal kegiatan yang akan dilakukan selama pendampingan.

b. Pendampingan Pembuatan Handout Workshop yang dilakukan pada kegiatan sebelumnya dilanjutkan dengan kegiatan pendampingan untuk menindak lanjuti. Kegiatan pendampingan yang dilakukan adalah membuat handout untuk olimpiade. Selain mendampingi guru, tim juga mendampingi siswa dalam menyelesaikan soal olimpiade.

c. Implementasi di Sekolah Rencana kegiatan yang sudah disusun sebelumnya untuk selanjutnya dilanjutkan dengan kegiatan implementasi di sekolah. Kegiatan ini dilakukan untuk melihat pelaksanaan dari rencana yang sudah dibuat sebelumnya dan untuk melihat implementasi dari handout yang sudah disusun sebelumnya. Implementasi ini dilakukan kurang lebih selama 5 kali pertemuan. Tim melihat proses pendampingan terhadap siswa dan guru SMKN 2 Bima.

d. Evaluasi dan Refleksi Selama kegiatan implementasi tim pengabdian melakukan evaluasi secara berkala dan berdiskusi untuk mengatasi kendala yang terjadi dan untuk melakukan penyempurnaan. Kendala-kendala tersebut yang terjadi untuk selanjutnya dicarikan solusi untuk dapat di implementasikan kembali dan diharapkan dapat mengatasinya. Setelah evaluasi, kegiatan selanjutnya adalah refleksi untuk keterlaksanaan kegiatan. Refleksi dilakukan setelah semua kegiatan berjalan, mulai dari perencanaan sampai dengan implementasi. Kegiatan refleksi 
ini dilakukan oleh tim pengabdian beserta dengan guru pendamping olimpiade dengan jalan tanya jawab dan diskusi. Kegiatan ini dilakukan guna mengetahui apa saja yang terjadi pada saat pelaksanaan berlangsung. Refleksi dilakukan selama 1 pertemuan.

\section{Hasil Kegiatan}

Kegiatan pengabdian berlangsung selama delapan bulan dengan rincian kegiatan sebagai berikut.

Tabel 1. Agenda Kegiatan Pengabdian

\begin{tabular}{|r|l|l|}
\hline \multicolumn{1}{l|}{ No } & Bulan Ke & Uraian Kegiatan \\
\hline 1. & 1 & Persiapan \\
\hline 2. & $2-5$ & Pendampingan \\
\hline 3. & $6-7$ & Implementasi \\
\hline 4. & 8 & Evaluasi dan refleksi \\
\hline
\end{tabular}

Adapun penjelasan dari setiap kegiatan adalah sebagai berikut.

a. Persiapan.

Kegiatan persiapan disini berlangsung selama satu bulan. Kegiatan persiapan diawali dengan observasi lapang dengan menemui guru dan kepala SMKN 2 Bima. Dari hasil observasi diperoleh data antara lain yaitu:

1. Guru mengalami permasalahan dalam mengatasi lomba olimpiade matematika setara SMK. Hal ini dikarenakan minimnya sarana dan prasarana yang mendukung. Guru matematika yang ada di sekolah tersebut hanya ada dua orang guru dan masing-masing mempunyai jadwal yang padat karena keterbatasan tenaga pendidik.

2. Pendampingan

Pendampingan dilakukan oleh tim pengabdian kepada dua orang siswa. Pendampingan dilakukan selama proses pembelajaran berlangsung. Hal ini dimaksudkan untuk memaksimalkan proses pembelajaran dan dapat diketahui keterlaksanaannya.

Pendampingan diikuti oleh 12 siswa SMKN 2 Bima dengan melibatkan TIM Pengabdian. Berdasarkan hasil dari implementasi diperoleh data bahwa siswa terlibat secara aktif selama proses pendampingan. Proses pendampingan berlangsung selama lima kali yaitu dua kali di
SMKN 2 Bima dan tiga kali pendampingan di UMM

3. Implementasi

Pelaksanaan kegiatan pengabdian ini berlangsung di sekolah dan di UMM. Hal ini dimaksudkan untuk memberikan referensi yang cukup terkait dengan kegiatan pengabdian. Berdasarkan hasil implementasi diperoleh data bahwa $60 \%$ siswa terlibat aktif selama proses implementasi. Siswa yang belum terlibat aktif diberikan bimbingan secara individu sehingga dapat mengikuti proses pembelajaran dengan baik.

4. Evaluasi dan refleksi

Setelah proses pendampingan berlangsung berikutnya adalah kegiatan evaluasi dan refleksi. Berdasarkan hasil revisi diperoleh bahwa : a) siswa kesulitan secara konseptual dan procedural terhadap pemecahan masalah matematika, b) guru dapat menambah referensi dengan terlibat aktif dalam forum guru yang di dalamnya terhadap beberapa orang guru olimpiade, dan c) perlunya kolaborasi antara PT dengan sekolah sehingga guru dapat terlibat aktif dalam meningkatkan pengetahuannya.

\section{Kesimpulan}

Hasil dari pengabdian ini adalah kegiatan pendampingan yang di dalamnya terdapat langkah-langkah: a) Analisis pendahuluan, b) penyusunan soal pemecahan masalah, c) Kegiatan pendampingan, d) kegiatan akhir yang berupa refleksi kegiatan.

\section{Saran}

Saran pada pengabdian ini adalah pembimbingan kepada siswa dapat dilakukan secara tatap muka maupun secara online. Hal ini dilakukan karena siswa dapat meningkatkan pengetahuannya baik secara konseptual maupun prosedural.

\section{Daftar Rujukan}

Bicknell, B. (2008). Gifted Students and the Role of Mathematics Competition. APMC 13,4(4), 16-20.

Darhim. (2012). Pengaruh Pembelajaran Matematika Kontekstual terhadap Sikap SiswaSekolah Dasar. [Online] Tersedia: 
Fakhrudin.(2010). Meningkatkan

Kemampuan Pemecahan Masalah

Matematik Siswa Melalui Pembelajaran dengan Pendekatan Open Ended. Tesis Sekolah Pascasarjana Universitas Pendidikan Indonesia. Bandung.

Hidayat, E. (2009). Peningkatan Kemampuan Komunikasi Matematik dan Kemandirian Belajar Siswa Sekolah Menengah Pertama dengan Menggunaka Pendekatan Matematika Realistik. Tesis Sekolah Pascasarjana Universitas Pendidikan Indonesia. Bandung.

IMO. International of Mathematics Olympiad. Diakses pada 17 Oktober 2016 dari www.imoofficial.org

Ratnaningsih, N. (2003). Mengembangkan Kemampuan Berpikir Matematik Siswa SMUMelalui Pembelajaran Berbasis Masalah. Tesis Sekolah Pascasarjana Universitas Pendidikan Indonesia. Bandung.

Russefendi, E.T. (2010). Perkembangan Pendidikan Matematika. Jakarta: Universitas Terbuka.

Sugiyono. (2009). Metode Penelitian Kuantitatif dan Kualitatif dan R\&D. Bandung : Alfabeta.

Sutawijaya,A dan Afgani,J. (2011). Pembelajaran Matematika. Jakarta: Universitas Terbuka 